\title{
Penerapan Metode Penghalusan Eksponensial Tunggal pada Prediksi Penjualan Air Minum dalam Kemasan
}

\author{
Dwi Handoko ${ }^{1)}$, Andriani KKW ${ }^{2}$, Retno Tri Vulandari ${ }^{3)}$. \\ 1) Sistem Informasi, STMIK Sinar Nusantara Surakarta \\ 2) Sistem Informasi Akuntansi, STMIK Sinar Nusantara Surakarta \\ 3) Teknologi Informasi, STMIK Sinar Nusantara Surakarta \\ 1)116400075.dwi@sinus.ac.id, ${ }^{2)}$ andrianikkw@sinus.ac.id, ${ }^{3)}$ retnotv@ sinus.ac.id
}

\begin{abstract}
Bottled Drinking Water Industry has grown rapidly to various provinces and cities throughout Indonesia now. The development of this industry is caused by high demand from consumers and the lower quality of raw water in springs and wells. PT. Cahaya Bumi Intanpari (CBI) is a company that produces drinking water gallons, bottles, and cups under the brand "AirMu". Sales of bottled water every month always fluctuate. The management of PT. Cahaya Bumi Intanpari requires an estimate of the amount of production for each type of bottled water to market demand in the future. Based on the description of the background in this study, a desktop-based application was designed and built. The research method included data collection and data analysis for this research. Its data collection included observation, interviews, and literature study. While its data analysis included diagrams of data flow. The forecasting model used to forecast the sales of bottled drinking water at PT. Cahaya Bumi Intanpari was time series. Meanwhile, the forecasting method in this research used single exponential smoothing. From the results of calculation testing, it was proven that the Single Exponential Smoothing method can be implemented in the AMDK sales forecasting system. Based on the validity test the prediction test results of bottled drinking water sales below $20 \%$ are included in the good criteria.
\end{abstract}

Keywords: Bottled Drinking Water Industry, Single Exponential Smoothing, Trend Linear Model.

\section{PENDAHULUAN}

Industri Air Minum Dalam Kemasan (AMDK) sekarang ini telah berkembang pesat ke berbagai provinsi dan kota di seluruh negara Indonesia. Perkembangan industri ini disebabkan karena permintaan yang banyak dari konsumen dan semakin rendahnya kualitas air baku pada sumber mata air maupun sumur. Terkait dengan pensjualan AMDK pada setiap bulan yang selalu naik turun,

Berdasarkan uraian latar belakang tersebut, maka dalam penelitian ini dirancang dan dibangun sebuah aplikasi berbasis desktop. Model peramalan yang digunakan dalam melakukan peramalan penjualan air minum dalam kemasan ini adalah time series atau dapat disebut deret waktu, dan metode peramalan yang digunakan adalah single exponential smoothing. Model ini di pilih karena data yang didapat mengandung pola stasioner yang mana pola tersebut cocok digunakan pada metode single exponential smooting.

Metode single exponential smoothing merupakan metode peramalan yang cukup baik untuk peramalan jangka panjang dan jangka menengah, terutama pada tingkat operasional suatu perusahaan, dalam perkembangan dasar matematis dari metode smoothing. Kelebihan utama dari metode single exponential smoothing adalah dilihat dari kemudahan dalam operasi yang relatif rendah, ada sedikit keraguan apakah ketepatan yang lebih baik selalu dapat dicapai dengan menggunakan quantitative system (QS) atau metode dekomposisi yang secara intuitif menarik, namun dalam hal ini jika diperlukan peramalan untuk ratusan item. (Margi \& Pendawa, 2015). 


\section{TINJAUAN PUSTAKA}

\subsection{Peramalan}

Peramalan merupakan gambaran keadaan perusahaan pada masa yang akan datang. Gambaran tersebut sangat penting bagi manajemen perusahaan karena dengan gambaran tersebut maka perusahaan dapat memprediksi langkah-langkah apa saja yang diambil dalam memenuhi permintaan konsumen. Ramalan memang tidak selalu tepat $100 \%$, karena masa depan mengandung masalah ketidakpastian, namun dengan pemilihan metode yang tepat dapat membuat peramalan dengan tingkat kesalahan yang kecil (Fachrurrazi, 2015).

\subsection{Metode Single Exponential Smoothing}

Pada metode single exponential smoothing bobot yang diberikan pada data yang ada adalah sebesar $\alpha$ untuk data yang terbaru, $\alpha(1-\alpha)$ untuk data yang lebih lama, dan seterusnya. Besarnya $\alpha$ adalah antara 0 dan 1 . Semakin mendekati 1 berarti data terbaru lebih diperhatikan (Vulandari \& Parwitasari, 2017). Secara matematis besarnya Peramalan adalah:

Keterangan:

$$
F_{t+1}=\alpha X_{t}+(1-\alpha) F_{t}
$$

$F_{t+1}:$ Ramalan untuk periode ke $\mathrm{t}+1$

$X_{t} \quad$ : Nilai riil periode ke $\mathrm{t}$

$F_{t} \quad$ : Ramalan untuk periode ke $\mathrm{t}$

Dengan demikian dapat dikatakan bahwa peramalan pada periode yang akan datang adalah ramalan sebelumnya ditambah $\alpha$ (alpha) dikalikan dengan kesalahan ramalan periode sebelumnya. Dalam melakukan peramalan dengan menggunakan metode single exponential smoothing (SES), besarnya $\alpha$ (alpha) ditentukan secara trial dan error sampai ditemukan $\alpha$ (alpha) yang menghasilkan forecast error terkecil. Metode ini lebih cocok digunakan untuk meramal data-data yang fluktuatif secara random (tidak teratur) (Kuniagara, 2017).

\subsection{MAPE (Mean Absolute Percentage Error)}

Mean Absolute Percentage Error (MAPE) dihitung dengan menggunakan kesalahan absolut pada tiap periode dibagi dengan nilai observasi yang nyata untuk periode itu (Hermawan, Widada, \& Vulandari, 2018). Kemudian, merata-rata kesalahan persentase mutlak tersebut. MAPE merupakan pengukuran kesalahan yang menghitung persentase penyimpangan antara data aktual dengan data peramalan (Krisma \& Azhari, 2019). Nilai MAPE dapat dihitung dengan persamaan sebagai berikut:

$$
\mathrm{MAPE}=\frac{1}{\mathrm{n}} \sum_{\mathrm{t}=1}^{\mathrm{n}}\left|\frac{\mathrm{X}_{\mathrm{t}}-\mathrm{F}_{\mathrm{t}}}{\mathrm{X}_{\mathrm{t}}}\right| \times 100 \%
$$

Keterangan:

A $\quad$ : Nilai aktual pada waktu ke $\mathrm{t}$

$\mathrm{F}_{\mathrm{t}} \quad$ : Nilai prediksi pada waktu ke $\mathrm{t}$

n : Banyak data

\subsection{Penelitan Terkait}

Penelitian mengenai perancangan aplikasi peramalan jumlah calon mahasiswa baru yang mendaftar menggunakan metode single exponential smoothing. Peramalan pada Universitas Islam Sumatera Utara untuk meramalkan jumlah calon mahasiswa baru yang mendaftar merupakan suatu sistem yang sangat di butuhkan pada universitas tersebut. Metode peramalan ini menitik-beratkan pada penurunan prioritas secara eksponensial pada objek pengamatan sebelumnya. Dalam pemulusan eksponensial atau exponential smoothing terdapat satu atau lebih parameter pemulusan yang ditentukan secara eksplisit, dan hasil ini menentukan bobot yang dikenakan pada nilai observasi (Purba, 2015). 
Penelitian mengenai peramalan penjualan obat menggunakan metode single exponential smoothing pada toko obat bintang geurugok. Adapun parameter atau alpha yang digunakan dalam meramalkan penjualan obat adalah alpha $=0.1$, alpha $=0.2$, alpha $=0.3$, alpha $=0.4$, alpha $=0.5$, alpha $=0.6$, alpha $=0.7$, alpha $=0.8$, dan alpha $=0.9$. Single exponential smoothing melakukan perbandingan dalam menentukan nilai alpha, dengan mencari nilai alpha tersebut secara acak sampai menemukan alpha yang memiliki error minimum dengan pencarian menggunakan metode MSE (Mean Square Error). Pada tahap uji sampel didapat bahwa peramalan penjualan obat pada obat Ambeven bulan Maret 2015 berjumlah 49 tablet (Fachrurrazi, 2015).

Penelitian mengenai penerapan metode single exponential smoothing untuk peramalan penggunaan waktu telepon di PT. Telkomsel Surabaya. Metode single exponential smoothing merupakan metode yang popular digunakan dalam peramalan karena memiliki kinerja yang baik. Metode ini memiliki nilai parameter dan punya pengaruh yang besar terhadap hasil peramalan. Dengan menemukan nilai optimal dari parameter $\alpha$ dengan menggunakan Ordinary least square sehingga akan mendapatkan nilai parameter yang optimal dan memperoleh hasil peramalan dengan hasil kesalahan (RMSE) kecil (Raharja, Angraeni, \& Vinarti, 2010).

Penelitian mengenai analisa dan penerapan metode single exponential smoothing untuk prediksi pada penjualan tertentu. Data yang akan diolah adalah data pada PT. Media Cemara, pada tahun 2015 dan disajikan pada data per bulan. Hasil yang didapatkan dari penelitian ini adalah hasil analisa dari metode eksponensial tunggal untuk memperoleh informasi prediksi penjualan dan tingkat keakuratannya dengan data MAD, MSE, MAPE (Margi \& Pendawa, 2015).

Penelitian mengenai sistem prediksi penjualan gamis toko qitaz menggunakan metode single exponential smoothing. Hasil yang didapatkan dari penelitian ini adalah hasil analisa dari metode eksponensial tunggal untuk memperoleh informasi prediksi penjualan dan tingkat keakuratannya dengan data MAD, MSE, MAPE untuk mencari error terkecil. Dari hasil pengujian terhadap sistem yang telah dibuat, system dapat meramalkan data penjualan gamis pada toko Qitaz sehingga sistem dapat membantu toko Qitaz dalam mengambil keputusan pada perkiraan stok produk dengan tepat (Alfarisi, 2017).

\section{METODE PENELITIAN}

Metode penelitian dalam penelitian ini adalah studi kasus dengan menggunakan data sekunder dari PT. Cahaya Bumi Intanpari Karanganyar untuk meramalkan penjualan Air Minum Dalam Kemasan (AMDK). Adapun tahap - tahap yang dilakukan dapat dilihat pada Gambar 1. 


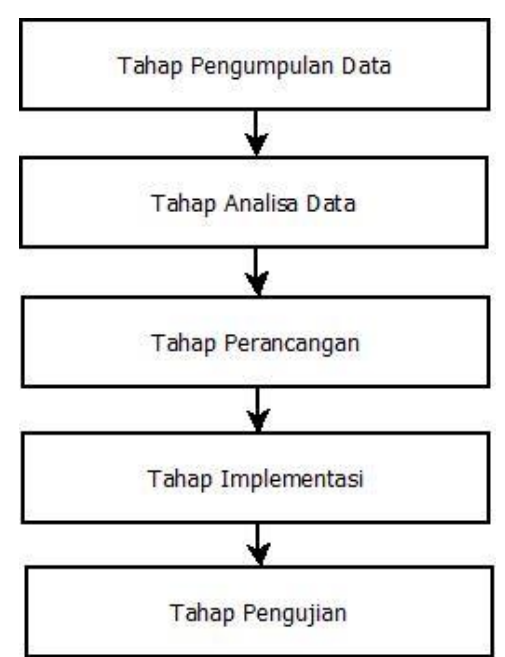

Gambar 1. Alur Pelaksanaan Penelitian

\subsection{Analisa Data}

Data yang digunakan pada penelitian ini berupa data hasil penjualan AMDK dari bulan Oktober 2018 - Agustus 2019 di PT. Cahaya Bumi Intanpari Karanganyar. Data tersebut di export kedalam format excel (.xls) untuk dilakukikan analisa dan perhitungan secara manual yang digunakan sebagai data peramalan. Data peramalan ini disusun dalam periode bulan, yaitu 12 periode dalam kurun satu tahun. Data - data tersebut dijabarkan dalam Gambar 2, Gambar 3, dan Gambar 4.

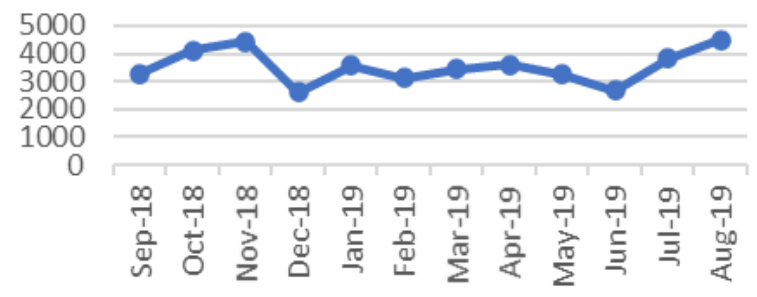

Gambar 2. Penjualan AMDK Jenis Galon

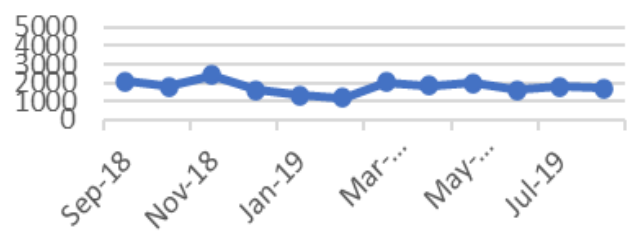

Gambar 3. Penjualan AMDK Jenis Botol

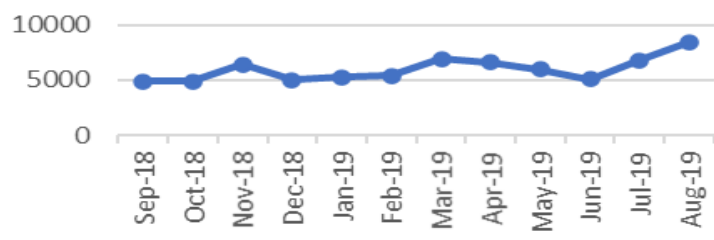

Gambar 4. Penjualan AMDK Jenis Gelas

\subsection{Perancangan}

Tahap perancangan dilakukan dengan merancang desain sistem dan desain antarmuka. Desain sistem ini menggunakan desain dalam bentuk Diagram Konteks, Hierarchy Input 
Process Output (HIPO), Data Flow Diagram (DFD). Sedangkan desain antarmuka terdiri dari beberapa form yaitu form login, Halaman Utama, Halaman Data Pengguna, Halaman Data Jenis AMDK, Halaman Transaksi, Halaman Peramalan / Forecasting, dan Laporan Hasil Peramalan.

\subsection{Implementasi}

Implementasi ini menghasilkan aplikasi peramalan penjualan AMDK di PT. Cahaya Bumi Intanpari Karanganyar. Aplikasi pendukung peramalan ini dibangun dengan memiliki fungsional utama antara lain:

a) Perhitungan peramalan dengan menggunakan metode Single Exponential Smoothing.

b) Perhitungan kesalahan peramalan atau error dengan MAPE.

Tahap implementasi sistem meliputi meliputi pembuatan database dengan Microsoft SQL Server, pengkodingan dengan bahasa pemrograman VB.net, dan tahap terakhir adalah pengkonversian program menjadi prototype exe.

\subsection{Pengujian}

Pengujian dalam penelitian ini ada dua jenis yaitu uji fungsionalitas sistem dan uji validitas. Uji fungsional dilakukan dengan metode blackbox testing yaitu untuk mencari kesalahan dan kekurangan dari sistem yang telah dibuat. Sedangkan pengujian validitas sistem ini dilakukan dengan metode MAPE (Mean Absolute Percentage Error).

Pada penelitian ini nilai MAPE dari hasil peramalan penjualan AMDK dimana nilai MAPE yang paling kecil maka akurasi peramalan akan semakin tinggi. Untuk mancari nilai MAPE menggunakan kesalahan absolut pada tiap periode dibagi dengan nilai observasi yang nyata untuk periode itu nanti hasilnya berupa persentase.

\section{HASIL DAN PEMBAHASAN \\ 4.1 Perhitungan Forecast AMDK}

\section{a. Jenis Galon}

Berdasarkan persamaan rumus 1 dengan menentukan $\alpha$ (alpha) sebesar 0,1 maka perhitungan prediksi data Tabel 1 dapat di uraikan sebagai berikut : $\boldsymbol{F}_{\boldsymbol{t}+\mathbf{1}}=\mathbf{0}, \mathbf{1}\left(\boldsymbol{X}_{\boldsymbol{t}}\right)+$ $(1-0,1) F_{t-1}$.

Data penjualan AMDK jenis galon pada bulan september 2018 sejumlah 3269 pcs. Untuk bulan september 2018 (F1) kita belum bisa meramalkannya. Untuk meramalkan bulan oktober 2018 kita belum memiliki cukup data karena kita belum dapat data hasil ramalan pada bulan September 2018. Jadi untuk meramalkan bulan oktober 2018 (F2) kita dapat menggunakan data paling terakhir yaitu bulan Januari sejumlah 3269 pcs.

Perhitungan pada bulan berikutnya sebagai berikut :

$$
\begin{aligned}
F_{2+1}(\text { Nov-18) } & =0,1\left(X_{2}\right)+(1-0,1) \mathrm{F} 2 \\
& =0,1(4122)+(0,9) 3269 \\
& =3354,3 \\
F_{3+1}(\text { Dec-18 }) & =0,1\left(X_{3}\right)+(1-0,1) \mathrm{F} 3 \\
& =0,1(4421)+(0,9) 3354,3 \\
& =3460,97 \\
F_{4+1}(\text { Jan-19) } & =0,1\left(X_{4}\right)+(1-0,1) \mathrm{F} 4 \\
& =0,1(2599)+(0,9) 3460,97 \\
& =3374,773 \\
F_{5+1}(\text { Feb-19) } & =0,1\left(X_{5}\right)+(1-0,1) \mathrm{F} 5 \\
& =0,1(3571)+(0,9) 3374,773 \\
& =3394,396
\end{aligned}
$$


Bobot $\alpha$ yang saya gunakan berikutnya adalah $\alpha=0,3$. Dapat di uraikan sebagai berikut: $\boldsymbol{F}_{t+1}=\mathbf{0 , 3}\left(\boldsymbol{X}_{t}\right)+(\mathbf{1}-\mathbf{0 , 3}) \boldsymbol{F}_{t-1}$

$$
\begin{aligned}
F_{2+1}(\text { Nov-18) } & =0,3\left(X_{2}\right)+(1-0,3) \mathrm{F} 2 \\
& =0,3(4122)+(0,7) 3269 \\
& =3524,9 \\
F_{3+1}(\text { Dec-18) } & =0,3\left(X_{3}\right)+(1-0,3) \mathrm{F} 3 \\
& =0,3(4421)+(0,7) 3524,9 \\
& =3793,73 \\
F_{4+1}(\text { Jan-19) } & =0,3\left(X_{4}\right)+(1-0,3) \mathrm{F} 4 \\
& =0,3(2599)+(0,7) 3793,73 \\
& =3435,311 \\
F_{5+1}(\text { Feb-19) } & =0,3\left(X_{5}\right)+(1-0,3) \mathrm{F} 5 \\
& =0,3(3571)+(0,7) 3435,311 \\
& =3475,018
\end{aligned}
$$

Bobot $\alpha$ yang saya gunakan berikutnya adalah $\alpha=0,8$. Dapat di uraikan sebagai berikut $\boldsymbol{F}_{\boldsymbol{t}+\mathbf{1}}=\mathbf{0 , 8}\left(\boldsymbol{X}_{\boldsymbol{t}}\right)+(\mathbf{1}-\mathbf{0 , 8}) \boldsymbol{F}_{\boldsymbol{t}-\mathbf{1}}$

$$
\begin{aligned}
F_{2+1}(\text { Nov-18 }) & =0,8\left(X_{2}\right)+(1-0,8) \mathrm{F} 2 \\
& =0,8(4122)+(0,2) 3269 \\
& =3951,4 \\
F_{3+1}(\text { Dec-18 }) & =0,8\left(X_{3}\right)+(1-0,8) \mathrm{F} 3 \\
& =0,8(4421)+(0,2) 3951,4 \\
& =4327,08 \\
F_{4+1}(\text { Jan-19) } & =0,8\left(X_{4}\right)+(1-0,8) \mathrm{F} 4 \\
& =0,8(2599)+(0,2) 4327,08 \\
& =2944,616 \\
F_{5+1}(\text { Feb-19) } & =0,8\left(X_{5}\right)+(1-0,8) \mathrm{F} 5 \\
& =0,8(3571)+(0,2) 2944,616 \\
& =3445,723
\end{aligned}
$$

Tabel 1. Hasil Forecast Jenis Galon

\begin{tabular}{|c|c|c|c|c|}
\hline \multirow{2}{*}{ Bulan } & \multirow{2}{*}{ Jumlah } & \multicolumn{3}{|c|}{ Forecast $\boldsymbol{\alpha}$} \\
\cline { 3 - 5 } & & $\mathbf{0 , 1}$ & $\mathbf{0 , 3}$ & $\mathbf{0 , 8}$ \\
\hline Sep-18 & 3269 & - & - & - \\
\hline Oct-18 & 4122 & 3269 & 3269 & 3269 \\
\hline Nov-18 & 4421 & 3354,3 & 3524,9 & 4036,7 \\
\hline Dec-18 & 2599 & 3460,97 & 3793,73 & 4382,57 \\
\hline Jan-19 & 3571 & 3374,773 & 3435,311 & 2777,357 \\
\hline Feb-19 & 3125 & 3394,396 & 3476,018 & 3491,636 \\
\hline Mar-19 & 3444 & 3367,456 & 3370,712 & 3161,664 \\
\hline Apr-19 & 3611 & 3375,111 & 3392,699 & 3415,766 \\
\hline May-19 & 3240 & 3398,699 & 3458,189 & 3591,477 \\
\hline Jun-19 & 2662 & 3382,83 & 3392,732 & 3275,148 \\
\hline Jul-19 & 3827 & 3310,747 & 3173,513 & 2723,315 \\
\hline Aug-19 & 4507 & 3362,372 & 3369,559 & 3716,631 \\
\hline
\end{tabular}




\section{b. Jenis Botol}

Perhitungan sama dengan perhitungan jenis galon dengan menggunakan $\alpha=0,1, \alpha$ $=0,3$ dan $\alpha=0,8$. Data yang digunakan adalah data jenis botol yang terdapat pada Tabel 2. Berikut adalah hasil forecast jenis botol yang dipaparkan dalam Tabel 2.

Tabel 2. Hasil Forecast Jenis Botol

\begin{tabular}{|r|r|r|r|r|}
\hline \multirow{2}{*}{ Bulan } & \multirow{2}{*}{ Jumlah } & \multicolumn{3}{|c|}{ Forecast $\boldsymbol{\alpha}$} \\
\cline { 3 - 5 } & & \multicolumn{1}{c|}{$\mathbf{0 , 1}$} & $\mathbf{0 , 3}$ & \multicolumn{1}{c|}{$\mathbf{0 , 8}$} \\
\hline Sep-18 & 2066 & - & - & - \\
\hline Oct-18 & 1786 & 2066 & 2066 & 2066 \\
\hline Nov-18 & 2423 & 2038 & 1982 & 1842 \\
\hline Dec-18 & 1607 & 2076,5 & 2114,3 & 2306,8 \\
\hline Jan-19 & 1321 & 2029,55 & 1962,11 & 1746,96 \\
\hline Feb-19 & 1207 & 1958,695 & 1769,777 & 1406,192 \\
\hline Mar-19 & 2029 & 1883,526 & 1600,944 & 1246,838 \\
\hline Apr-19 & 1876 & 1898,073 & 1729,361 & 1872,568 \\
\hline May-19 & 2005 & 1895,866 & 1773,353 & 1875,314 \\
\hline Jun-19 & 1616 & 1906,779 & 1842,847 & 1979,063 \\
\hline Jul-19 & 1784 & 1877,701 & 1774,793 & 1688,613 \\
\hline Aug-19 & 1735 & 1868,331 & 1777,555 & 1764,923 \\
\hline
\end{tabular}

\section{c. Jenis Gelas}

Perhitungan sama dengan perhitungan jenis galon dengan menggunakan $\alpha=0,1, \alpha$ $=0,3$ dan $\alpha=0,8$. Data yang digunakan adalah data jenis gelas yang terdapat pada Tabel 3. Berikut adalah hasil forecast jenis gelas yang dipaparkan dalam Tabel 3.

Tabel 3. Hasil Forecast Jenis Gelas

\begin{tabular}{|r|r|r|r|r|}
\hline \multirow{2}{*}{ Bulan } & \multirow{2}{*}{ Jumlah } & \multicolumn{3}{|c|}{ Forecast $\boldsymbol{\alpha}$} \\
\cline { 3 - 5 } & & \multicolumn{1}{c|}{$\mathbf{0 , 1}$} & \multicolumn{1}{c|}{$\mathbf{0 , 3}$} & \multicolumn{1}{c|}{$\mathbf{0 , 8}$} \\
\hline Sep-18 & 4912 & - & - & \multicolumn{1}{c|}{} \\
\hline Oct-18 & 4887 & 4912 & 4912 & 4912 \\
\hline Nov-18 & 6424 & 4909,5 & 4904,5 & 4892 \\
\hline Dec-18 & 5032 & 5060,95 & 5360,35 & 6117,6 \\
\hline Jan-19 & 5285 & 5058,055 & 5261,845 & 5249,12 \\
\hline Feb-19 & 5389 & 5080,75 & 5268,792 & 5277,824 \\
\hline Mar-19 & 6969 & 5111,575 & 5304,854 & 5366,765 \\
\hline Apr-19 & 6613 & 5297,317 & 5804,098 & 6648,553 \\
\hline May-19 & 6016 & 5428,885 & 6046,768 & 6620,111 \\
\hline Jun-19 & 5108 & 5487,597 & 6037,538 & 6136,822 \\
\hline Jul-19 & 6794 & 5449,637 & 5758,677 & 5313,764 \\
\hline Aug-19 & 8486 & 5584,073 & 6069,274 & 6497,953 \\
\hline
\end{tabular}

\subsection{Uji Validitas}

Metode pengukuran kesalahan peramalan yang digunakan oleh penulis adalah Mean Absolute Percentage Error (MAPE) dengan berdasarkan persamaan rumus 2. . Hasil pengukuran kesalahan/uji validitas AMDK jenis galon, botol dan gelas terlampir pada Tabel 4. 
Tabel 4. Hasil uji validitas AMDK

\begin{tabular}{|c|c|c|c|c|c|c|c|c|c|c|c|c|}
\hline \multirow[t]{2}{*}{ Bulan } & \multirow{2}{*}{$\begin{array}{l}\text { Jenis } \\
\text { Galon }\end{array}$} & $\alpha=0,1$ & $\alpha=0,3$ & $\alpha=0,8$ & $\begin{array}{l}\text { Jenis } \\
\text { Botol } \\
\end{array}$ & $\alpha=0,1$ & $\alpha=0,3$ & $\alpha=0,8$ & $\begin{array}{l}\text { Jenis } \\
\text { Gelas } \\
\end{array}$ & $\alpha=0,1$ & $\alpha=\mathbf{0 , 3}$ & $\alpha=\mathbf{0 , 8}$ \\
\hline & & MAPE & MAPE & MAPE & & MAPE & MAPE & MAPE & & MAPE & MAPE & MAPE \\
\hline Sep-18 & 3269 & - & - & - & 2066 & - & - & - & 4912 & & & \\
\hline Oct-18 & 4122 & $20,69 \%$ & $200 \%$ & $20,69 \%$ & 1786 & $15,68 \%$ & $15,68 \%$ & $15,68 \%$ & 4887 & & & $0,51 \%$ \\
\hline Nov-18 & 4421 & & & & 2423 & $15,89 \%$ & $10,207 \%$ & $23,98 \%$ & 6424 & & $23,65 \%$ & $23,85 \%$ \\
\hline Dec-18 & 2599 & $33,17 \%$ & $4 \mathrm{4}, 91 \%$ & $66,49 \%$ & 1607 & $29,22 \%$ & $31,51 \%$ & $43,55 \%$ & 5032 & $0,58 \%$ & $6,53 \%$ & $21,57 \%$ \\
\hline Jan-19 & & $50 \%$ & $80 \%$ & $17,54 \%$ & 1321 & $53,64 \%$ & $48,53 \%$ & $32,25 \%$ & 5285 & $4,29 \%$ & $0,44 \%$ & $0,68 \%$ \\
\hline Feb-19 & 3125 & $8,62 \%$ & $11,23 \%$ & $10,26 \%$ & 1207 & $62,28 \%$ & $46,63 \%$ & $16,50 \%$ & 5389 & $5,72 \%$ & $2,23 \%$ & $2,06 \%$ \\
\hline Mar-19 & 3444 & $220 \%$ & $2,13 \%$ & $7,40 \%$ & 2029 & $7,17 \%$ & $21,10 \%$ & $38,55 \%$ & 6969 & $26,65 \%$ & $23,88 \%$ & $22,99 \%$ \\
\hline Apr-19 & & & & & 1876 & & & $0,18 \%$ & 6613 & & $12,23 \%$ & $0,54 \%$ \\
\hline May-19 & & & & $10,11 \%$ & 2005 & & $11,55 \%$ & $6,47 \%$ & 6016 & & & $10,04 \%$ \\
\hline Jun-19 & & $27,08 \%$ & $27,45 \%$ & $24,17 \%$ & 1616 & $17,99 \%$ & $14,04 \%$ & $22,47 \%$ & 5108 & & $18,20 \%$ & $20,14 \%$ \\
\hline Jul-19 & 3827 & $3,49 \%$ & $17,08 \%$ & $27,08 \%$ & 1784 & $5,25 \%$ & $0,52 \%$ & $5,35 \%$ & 6794 & $19,79 \%$ & $15,24 \%$ & $21,79 \%$ \\
\hline Aug-19 & 4507 & $25,40 \%$ & $25,24 \%$ & $19,69 \%$ & 1735 & $7,68 \%$ & $2,45 \%$ & $1,72 \%$ & 8486 & $34,20 \%$ & $28,48 \%$ & $23,43 \%$ \\
\hline MAPE & & $15,61 \%$ & $16,97 \%$ & $20,01 \%$ & $\begin{array}{l}\text { MAPE } \\
(\%)\end{array}$ & $20,13 \%$ & $19,83 \%$ & $18,79 \%$ & $\begin{array}{l}\text { MAPE } \\
(\%)\end{array}$ & $13,85 \%$ & $11,99 \%$ & $13,42 \%$ \\
\hline
\end{tabular}

Berdasarkan Tabel 4 Validitas AMDK Jenis Galon maka diperoleh rata-rata kesalahan prediksi menggunakan nilai $\alpha=0,1$ sebesar $15,61 \%$ dengan tingkat akurasi $84,39 \%, \alpha=0,3$ sebesar $16,97 \%$ dengan tingkat akurasi $83,03 \%$ dan $\alpha=0,8$ sebesar $20,01 \%$ dengan tingkat akurasi 79,99\%. Berdasarkan Tabel 4 Validitas AMDK Jenis Botol maka diperoleh rata-rata kesalahan prediksi menggunakan nilai $\alpha=0,1$ sebesar $20,13 \%$ dengan tingkat akurasi $79,87 \%, \alpha=0,3$ sebesar $19,83 \%$ dengan tingkat akurasi $80,17 \%$ dan $\alpha=0,8$ sebesar $18,79 \%$ dengan tingkat akurasi $81,21 \%$. Berdasarkan Tabel 4 Validitas AMDK Jenis Gelas maka diperoleh rata-rata kesalahan prediksi menggunakan nilai $\alpha=0,1$ sebesar $13,85 \%$ dengan tingkat akurasi $86,15 \%, \alpha=0,3$ sebesar $11,99 \%$ dengan tingkat akurasi $88,01 \%$ dan $\alpha=0,8$ sebesar $13,42 \%$ dengan tingkat akurasi $86,58 \%$

\section{IMPLEMENTASI}

\subsection{Implementasi Sistem}

Hasil implementasi sistem dari aplikasi peramalan penjualan AMDKsebagai berikut.

- Halaman Utama

Tampilan halaman utama ditunjukkan pada Gambar 5.

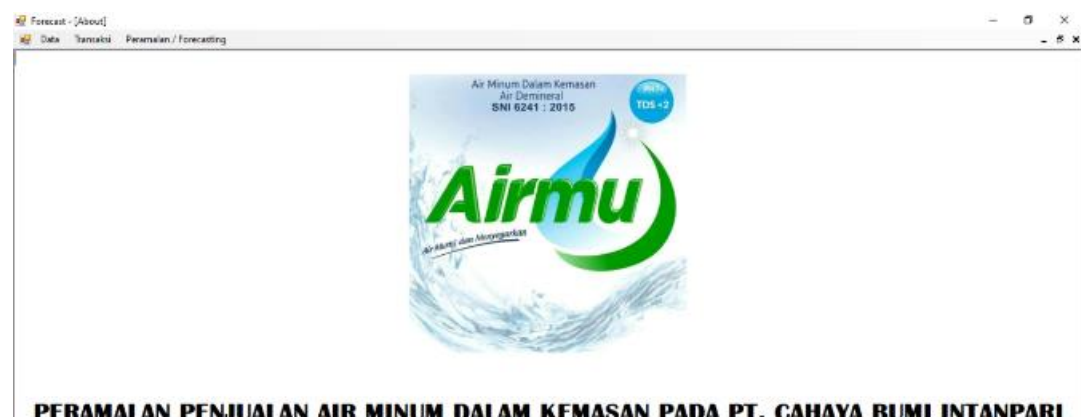

PERAMalan PENJUAlan AIR Minum dalam KEMASAN PADA PT. CAHAYA BUMI INTANPARI KARANGANYAR MENGGUNAKAN METODE SINGLE EXPONENTIAL SMOTHING

Gambar 5. Halaman utama 
- Halaman Transaksi

Tampilan halaman transaksi ditunjukkan pada Gambar 6.

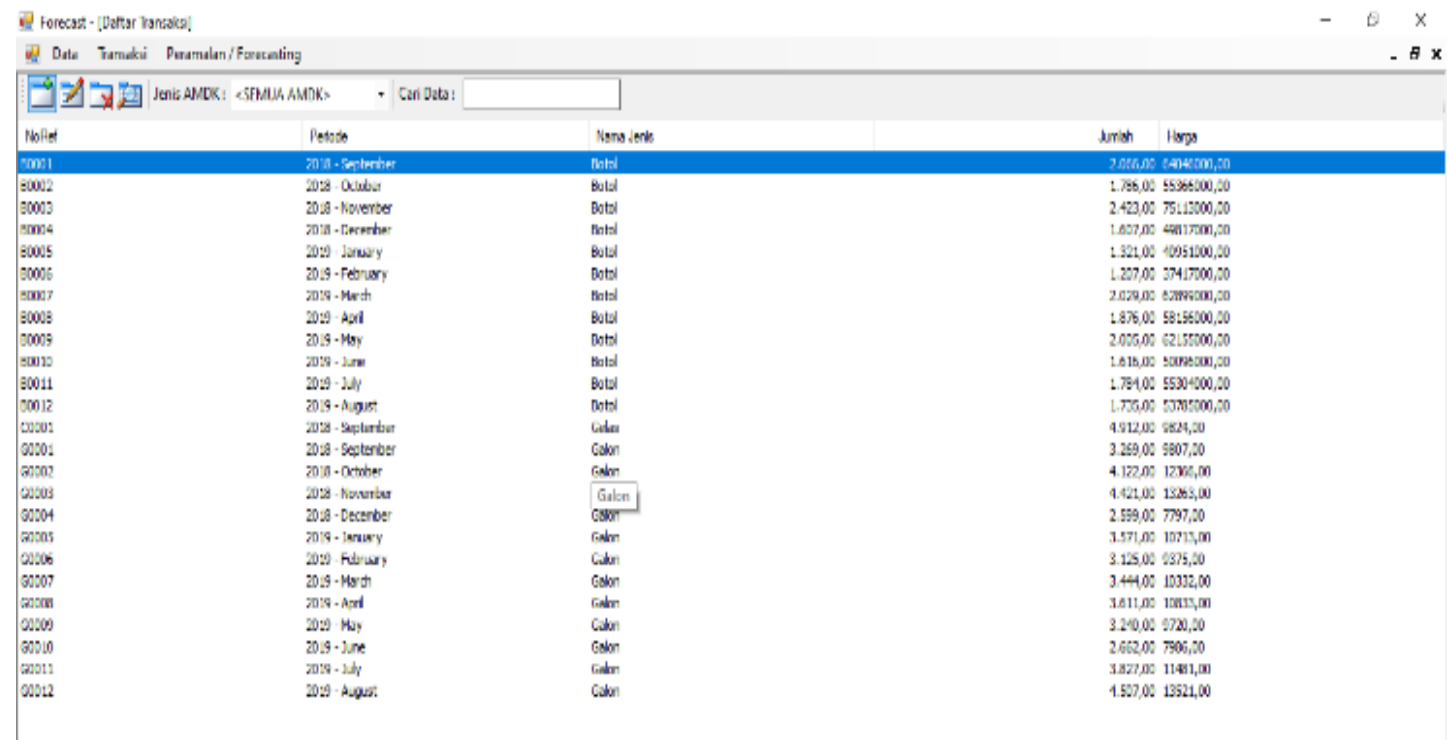

Gambar 6. Halaman transaksi

- Halaman Peramalan / Forecasting

Tampilan halaman peramalan / forecasting ditunjukkan pada Gambar 7.

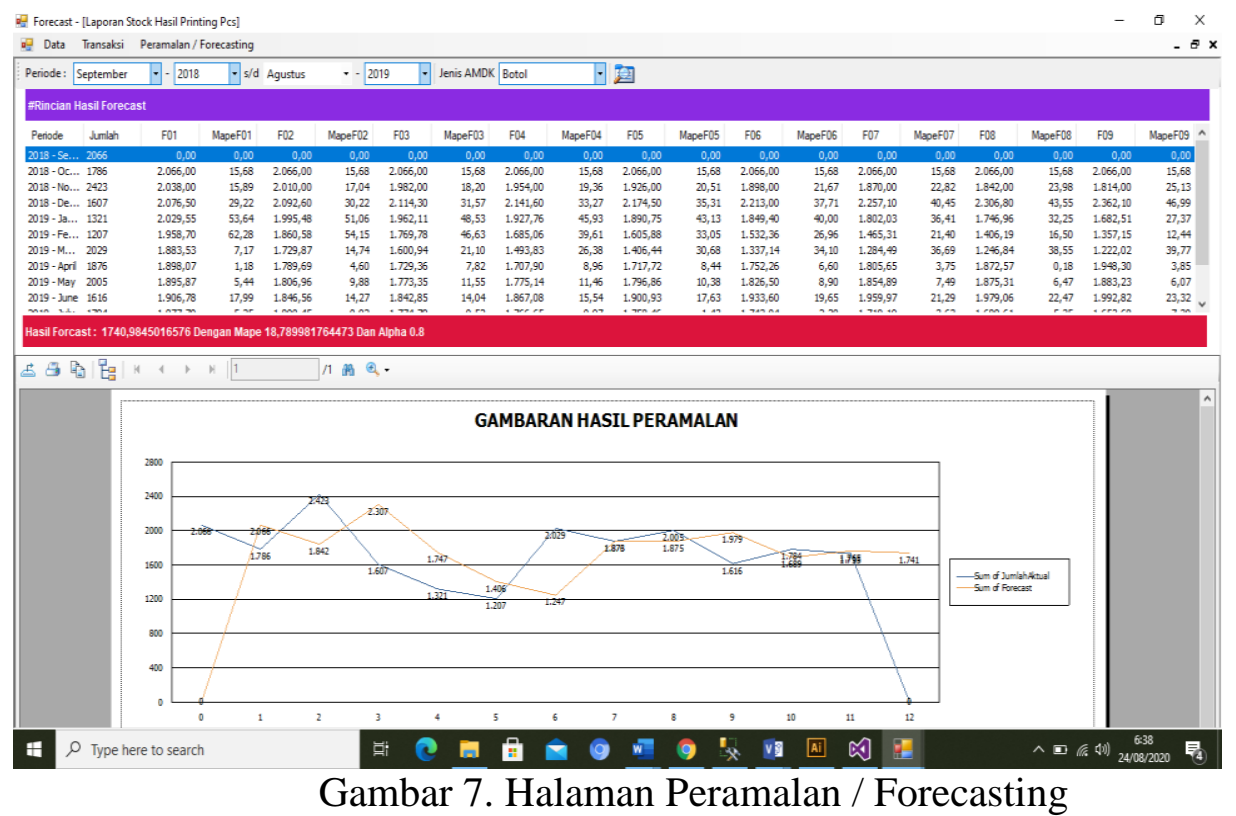

- Halaman Laporan Peramalan

Tampilan halaman laporan peramalan ditunjukkan pada Gambar 8 . 


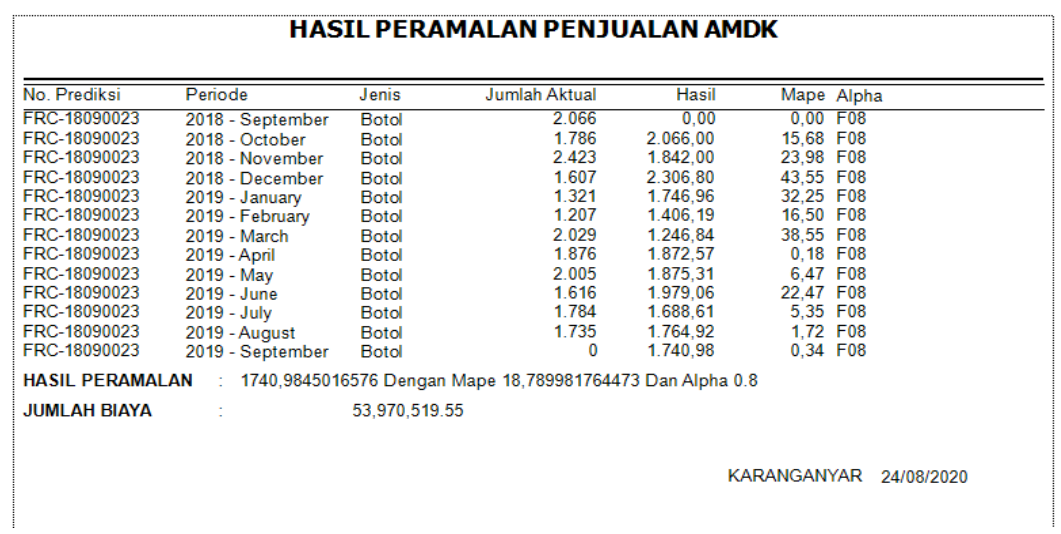

Gambar 8. Laporan Peramalan

\subsection{Pengujian Fungsional}

Pengujian fungsional ini menggunakan pengujian black box. Berikut hasil dari pengujian black box yang ditunjukkan pada Tabel 5.

Tabel 5. Hasi Pengujian Black Box

\begin{tabular}{|c|c|}
\hline Sistem yang diuji & Hasil Pengujian \\
\hline Login admin / pengguna & Tampil halaman utama \\
\hline Menu data pengguna & Tampil halaman data pengguna \\
\hline Battom tambah data & $\begin{array}{l}\text { Muncul form tambah data } \\
\text { Menyimpan data } \\
\text { Keluar dari form tambah data }\end{array}$ \\
\hline Battom edit data & $\begin{array}{l}\text { Muncul form edit data } \\
\text { Menyimpan data } \\
\text { Keluar dari form edit data }\end{array}$ \\
\hline Battom hapus data & Tampil data setelah dihapus sesuai yang diharapkan \\
\hline Battom Refresh data & Tampil data setelah direfresh sesuai yang diharapkan \\
\hline Cari data & Menampilkan data yang di cari \\
\hline Menu data jenis AMDK & Tampil halaman data jenis AMDK \\
\hline Battom tambah data & $\begin{array}{l}\text { Muncul form tambah data } \\
\text { Menyimpan data } \\
\text { Keluar dari form tambah data }\end{array}$ \\
\hline Battom edit data & $\begin{array}{l}\text { Muncul form edit data } \\
\text { Menyimpan data } \\
\text { Keluar dari form edit data }\end{array}$ \\
\hline Battom hapus data & Tampil data setelah dihapus sesuai yang diharapkan \\
\hline Battom refresh data & Tampil data setelah direfresh sesuai yang diharapkan \\
\hline Cari data & Menampilkan data yang di cari \\
\hline Menu transaksi & Tampil halaman transaksi/penjualan \\
\hline Battom tambah data & $\begin{array}{l}\text { Muncul form tambah data } \\
\text { Menyimpan data } \\
\text { Keluar dari form tambah data }\end{array}$ \\
\hline Battom edit data & $\begin{array}{l}\text { Muncul form edit data } \\
\text { Menyimpan data } \\
\text { Keluar dari form edit data }\end{array}$ \\
\hline Battom hapus data & Tampil data setelah dihapus sesuai yang diharapkan \\
\hline Battom refresh data & Tampil data setelah direfresh sesuai yang diharapkan \\
\hline Cari data & Menampilkan data yang di cari \\
\hline Menu Peramalan / forecasting & Menampilkan halaman peramalan \\
\hline Proses jenis galon & $\begin{array}{l}\text { Tampil rincian hasil perhitungan dan nilai mape } \\
\text { Tampil laporan hasil peramalan }\end{array}$ \\
\hline Proses jenis botol & $\begin{array}{l}\text { Tampil rincian hasil perhitungan dan nilai mape } \\
\text { Tampil laporan hasil peramalan }\end{array}$ \\
\hline Proses jenis gelas & $\begin{array}{l}\text { Tampil rincian hasil perhitungan dan nilai mape } \\
\text { Tampil laporan hasil peramalan }\end{array}$ \\
\hline
\end{tabular}




\subsection{Pengujian Validitas}

Pengujian validitas sistem ini dilakukan dengan metode pengujian MAPE (Mean Absolute Percentage Error) dan dihitung dengan menggunakan aplikasi Microsoft Excel. Data pengujian yang digunakan adalah data dari tahun 2015 sampai dengan 2018. Hasil MAPE data kuartal dan tahunan adalah sebagai berikut.

1. Hasil pengujian tingkat error prediksi pada kuartal 1 didapatkan hasil $3,43 \%$

2. Hasil pengujian tingkat error prediksi pada kuartal 2 didapatkan hasil 7,95\%

3. Hasil pengujian tingkat error prediksi pada kuartal 3 didapatkan hasil $4,84 \%$

4. Hasil pengujian tingkat error prediksi pada data tahunan didapatkan hasil $13,245 \%$

\section{KESIMPULAN DAN SARAN}

\subsection{Kesimpulan}

Berdasarkan analisa dan implementasi dari peramalan penjualan air minum dalam kemasan menggunakan single exponential smoothing, maka dapat diambil kesimpulan sebagai berikut:

1. Aplikasi berbasis destop yang mengimplementasikan metode single exponential smoothing dapat meramalan penjualan air minum dalam kemasan pada periode berikutnya.

2. Untuk mencari hasil peramalan penjualan yang akurat dilakukan dengan mencari nilai MAPE yang terkecil dengan membandingkan nilai $\alpha$ yang berbeda. Dengan hasil nilai MAPE yang paling kecil sehingga ramalan yang dihasilkan lebih akurat.

3. Hasil dari perhitungan manual maupun perhitungan menggunakan aplikasi metode single exponential smoothing menghasilkan nilai Forecast dan nilai MAPE yang sama.

4. Hasil uji validitas jenis galon diperoleh rata-rata kesalahan prediksi menggunakan nilai $\alpha=0,1$ sebesar $15,61 \%$ dengan tingkat akurasi $84,39 \%$

5. Hasil uji validitas jenis botol diperoleh rata-rata kesalahan prediksi menggunakan nilai $\alpha=0,8$ sebesar $18,79 \%$ dengan tingkat akurasi $81,21 \%$

6. Hasil uji validitas jenis botol diperoleh rata-rata kesalahan prediksi menggunakan nilai $\alpha=0,3$ sebesar $11,99 \%$ dengan tingkat akurasi $88,01 \%$

\subsection{Saran}

Adapun saran yang dapat peneliti sampaikan agar penelitian terus berkembang pada penelitian berikutnya yaitu:

1. Untuk penelitian selanjutnya diharapkan ada penelitian menggunakan metode lainnya untuk membandingkan tingkat nilai akurasinya.

2. Data yang digunakan dalam pengujian sebaiknya ditambah. Penggunaan data dengan volume yang lebih banyak dapat membantu mengurangi kesalahan persamaan peramalan yang dihasilkan.

\section{DAFTAR PUSTAKA}

Alfarisi, S. (2017). Sistem Prediksi Penjualan Gamis Toko QITAZ Menggunakan Metode Single Exponential Smoothing. JABE (Journal of Applied Business and Economic), 4(1), 80. https://doi.org/10.30998/jabe.v4i1.1908

Fachrurrazi, S. (2015). Menggunakan Metode Single Exponential Smoothing pada Toko Obat Bintang Geurugok. Techsi, 7(1), 19-30. https://doi.org/10.29103/techsi.v7i1.178

Hermawan, D. D., Widada, B., \& Vulandari, R. T. (2018). Perbandingan Hasil Panen Padi Dipengaruhi Rata-Rata Curah Hujan Atau Irigasi dengan Model Regresi Nonlinier Kubik di Kabupaten Sukoharjo. Jurnal TiKomSiN, 6(1), 6-10. 
Krisma, A., \& Azhari, M. (2019). Perbandingan Metode Double Exponential Smoothing Dan Triple Exponential Smoothing Dalam Parameter Tingkat Error Mean Absolute Percentage Error ( MAPE ) dan Means Absolute Deviation ( MAD ), 4(2), 81-87.

Kuniagara. (2017). Penerapan Metode Exponential Smoothing dalam Memprediksi Jumlah Siswa Baru ( Studi Kasus: Smk Pemda Lubuk Pakam ). Jurnal Pelita Informatika, 16(3), 214-220.

Margi, K., \& Pendawa, S. (2015). Analisa dan Penerapan Metode Single Exponential Smoothing untuk Prediksi Penjualan pada Periode Tertentu (Studi Kasus : PT. Media Cemara Kreasi). Prosiding SNATIF, 3(1998), 259-266.

Purba, A. (2015). Perancangan Aplikasi Peramalan Jumlah Calon Mahasiswa Baru yang mendaftar menggunakan Metode Single Exponential Smoothing (Studi Kasus: Fakultas Agama Islam UISU). Jurnal Riset Komputer (JURIKOM), 2(6), 8-12.

Raharja, A., Angraeni, W., \& Vinarti, R. A. (2010). Penerapan Metode Exponential Smoothing untuk Peramalan Penggunaan Waktu Telepon di PT. Telkomsel Divre3 Surabaya. Jurnal Sistem Informasi SISFO, 34(1), 86-96.

Vulandari, R. T., \& Parwitasari, T. A. (2017). Analisa Runtun Waktu Statistika dengan EViews (1st ed.). Surabaya: Mavendra Pers. 